\title{
SPILLING BLOOD WITHOUT MESS
}

The way in which the University Grants Committee has set about rationalizing the schools of agriculture at British universities is an important innovation, but it is not yet time for the defenders of academic freedom to rush to the barricades. Distinguished ex-presidents of the National Farmers' Union may feel themselves threatened, but there is no reason why academics should interpret the plan to do something about agriculture as a sinister plot against the freedom of the universities. On the face of things, at least, the University Grants Committee has a good case. Although by resting the case for a simpler pattern of undergraduate teaching on a report of a committee which finished deliberating more than two decades ago the U.G.C. may be somewhat vulnerable, the size of the demand for graduate agriculturists is not really the crucial consideration. The strongest argument in favour of rationalization is that the twelve schools of agriculture in Britain produce an average of fewer than forty graduates each year, and many of these are labelled diversely as horticulturists, foresters and the like. The chances are high that there is a more efficient way of producing graduate agriculturists.

But if the case for rationalizing in agriculture is strong, it does not follow that the U.G.C. should be cheered on whenever it conceives of a plan to make the organization of universities simpler, cheaper or more efficient. On the contrary, it will need to be watched with extra care now that its efforts to mould the pattern of teaching have gone beyond the discouragement of unwanted innovation to the closing down of unwanted institutions. It is also, however, fair to recognize that the U.G.C. has some difficult problems to contend with. The need to make better use of the facilities which exist-people and plant-has if anything been aggravated by the frequently uncritical acceptance of the assumption of the Robbins Report that a bigger university population must mean more universities on the traditional pattern. In retrospect, there is bound to be a conflict between the reasonable wish of the existing universities, new and old, to teach what they want to teach, and the plain fact that teaching must be on a sufficiently big scale if teachers and students are to get the best out of it. One way out of many present difficulties would be the emergence of a regional pattern of federation for British universities, but that is obviously a distant goal or even just a pipe-dream. Of necessity, the U.G.C. is forced to act where opportunities occur.

But is it acting wisely? Is it sensible to persuade some universities to stop doing things some of them at least want to continue? Might it not be better to take a more positive line, and to encourage the concentration of teaching at a smaller number of centres by channelling extra funds in the directions that seem most profitable? Experience elsewhere, and particularly in the United States, has shown how the establishment of what are called centres of excellence in particular fields can serve to force the pace of innovation and improvement. But they could also help to concentrate teaching in a smaller number of institu. tions. In the particular circumstances of higher education in agriculture at British universities, there may be reasons for thinking that the supply of graduates is adequate, but in the nature of things nobody can be sure that there is no room for valuable changes in the character of teaching. In other words, the U.G.C. might have done a service to agriculture and to its own reputation by looking for a more positive way of attaining its reasonable ends.

There remains the question of who should say what ends are worth attaining. In deciding on the rationalization of agriculture, the U.G.C. seems to have acted off its own bat. Prompted, no doubt, by the need to make the best of what funds it has to spend, the committee has found what seems to be a field in which economies are possible. No doubt the subject panel responsible for agriculture has helped enormously with drafting the detailed proposals circulated to the universities affected, but responsibility rest.s with the main committee of the U.G.C., and cannot easily be questioned. There are several risks in this procedure, not the least of which is that the U.G.C. may sometimes be wrong. In the long run, it should be for the universities as such, and not for the U.G.C., to say how best the pattern of university teaching should be made to meet the reasonable needs identified by the U.G.C. The one who pays the piper may call the tune, but it is not for him to decide just how it should be played. It does not help that the U.G.C. seeks advice from a panel of academics appointed for the purpose. Even if the U.G.C. were to relax its baffling unwillingness to make public the membership of its subject panels, the plain fact is that those who give advice must act as private individuals and not as representatives of the universities. What is needed is some procedure by means of which the U.G.C. could make a case for economy to the universities as a whole, and in which the universities could work out among themselves the best way of responding. This is yet another burden that must eventually be carried by the Committee of Vice-Chancellors and Principals.

\section{POLITICAL SCIENTISTS}

THE activities of science and technology have not become political issues as quickly in Britain as in the 